\section{A Markedly Anti-lipotropic Action of Methionine}

WHEN adult male rats are fed a protein-free, otherwise adequate diet, liver neutral lipid is doubled after 4 weeks of feeding ${ }^{1}$. In a more detailed and extended investiga. tion of the interrelationships of dietary protein-level and lipid metabolism in the rat, we have examined the possibility of alleviating the fatty liver produced in protein deficiency by including a low level of the ordinarily lipotropic agent, methionine, in a protein-free ration. When this was done it was observed that the livers increased markedly in size and became light brown in colour and very friable. Further investigation revealed that the livors had become very fatty.

Adult male Sprague-Dawley rats were separated into 4 groups (I-IV) and fed the diets listed here. The basal semi-synthetic diet has been described previously ${ }^{2}$ and consisted of 20 per cent casein, $0 \cdot 3$ per cent DL-methionine, 63.5 per cent glucose monohydrate, 5 per cent corn oil, 6.5 per cent salts, 0.2 per cent choline chloride, 0.02 per cent iso-inositol, and $\mathbf{4 . 5}$ per cent water-soluble vitamin mix. Fat-soluble vitamins were given separately to each rat. The groups and dietary treatments are given in Table 1. Groups I-III were fod ad libitum. Groups II and III consumed almost identical amounts of ration per day. After 8 weeks the rats were killed and the livers were extracted for lipids by the procedure of Folch et al. ${ }^{3}$. Total lipid was assayod by the method of Bragdon"; phospholipid, by the method of Fiske and Subbarow ${ }^{5}$ and total cholesterol, by the method of Pearson et al. ${ }^{6}$. Neutral glycerides were calculated by difference between total lipid and phospholipid plus cholesterol and calculating this difforence as $\mu$ moles of tripalmitin. All results are expressed as umoles of constituent per gram of liver.

The results are summarized in Table 1. Table 1. INFLUENOR OF a Low LEVEL OF METHIONINE ON LIVER LIPIDS

\begin{tabular}{|c|c|c|c|c|c|}
\hline Group & $\begin{array}{l}\text { No, of } \\
\text { rats }\end{array}$ & Diet & $\begin{array}{l}\text { Lipid conc } \\
\text { Neutral } \\
\text { glycerides }\end{array}$ & $\begin{array}{l}\text { entrations ( } \mu \mathrm{m} \\
\text { Phosphelipids }\end{array}$ & $\begin{array}{l}\text { noles/g liver) } \\
\text { Total } \\
\text { cholesterol }\end{array}$ \\
\hline II & $\begin{array}{l}10 \\
10\end{array}$ & $\begin{array}{l}\text { Basal, ad libitum } \\
\text { Basal less casein and } \\
\text { methionine, ad }\end{array}$ & $5.57 \pm 0.80$ & $32 \cdot 0 \pm 1 \cdot 1$ & $5 \cdot 41 \pm 0 \cdot 25$ \\
\hline III & 10 & $\begin{array}{l}\text { libitum } \\
\text { Basal, less casein, }\end{array}$ & $40 \cdot 1 \pm 5 \cdot 5$ & $25 \cdot 1 \pm 0 \cdot 54$ & $8.83 \pm 0.65$ \\
\hline IV & 10 & $\begin{array}{l}\text { ad libitum } \\
\text { Same as I, except } \\
\text { pair-fed with } \\
\text { Group II }\end{array}$ & $93 \cdot 7 \pm 8 \cdot 6$ & $26 \cdot 7 \pm 0.98$ & $\begin{array}{l}12 \cdot 8 \pm 0 \cdot 11 \\
5 \cdot 53 \pm 0 \cdot 11\end{array}$ \\
\hline
\end{tabular}

In the simple protein deficiency (Group II) liver neutral glyceride concentration was increased to 7 times that of the normal controls (Group I) or 8.5 times that of the pair-fed controls (Group IV). When 0.3 per cent DLmathionine was included in the protein-free ration (Group III), neutral glyceride concentration was further increased to 17 times that of the normal controls or 20 times that of the pair-fed controls. Neutral glycerides of the pair-fed controls (Group IV), which were included to obviate misinterpretation of the results because of discrepancies in food intake, were unchanged from normal. (Food intakes of Groups II and III, and thus of Group IV, fell to about 70 per cent of normal after 1 week and slowly decreased thereafter until, after 8 weeks, they were 50 per cent of normal.) Phospholipids were slightly decreased to about the same extent in the 2 protein-deficient groups. Liver cholesterol was increased to 1.5 times normal by the simple protein deficiency. Inclusion of methionine caused a further increase in cholesterol to about $2 \cdot 5$ times normal.

Thus it can be seen that the fatty liver induced by the low level of methionine in the protein-free ration is due almost entirely to accumulation of neutral glycerides with some contribution by cholesterol.

Preliminary results with gas chromatographic analysis of the fatty acids in the livers of the various groups indi- cates that the excess lipid found in the livers of Group III is composed of the same pattern of fatty acids as that of Group II. Thus the excess liver lipid induced by methionine in a protein-free ration appears to be a marked exacerbation of the moderately fatty liver condition produced by the protein-free ration alone.

Other preliminary results indicate that cystine at an equivalent concentration produces effects similar to those of methionme on liver lipids. Valine also has a similar effect but to a lesser extent. No other essential aminoacid, glutamic acid, or arginine produced this effect.

\section{J. N. Williams, Jon \\ A. D. JASIK}

National Institute of Arthritis and Metabolic Diseases, National Institutes of Health, Bethesda, Maryland.

1 Kosterlitz, H. W., J. Physiol., 106, 194 (1947).

2 Williams, jun., J. N., J. Nutrition, 73, 199 (1961).

'Folch, J., Lees, M., and Sloane-Stanley, G. H., J. Biol. Chem., 226, 497 (1957).

- Bragdon, J. H., J. Biol. Chem., 190, 513 (1951).

5 Fiske, C. H., and Subbarow, Y., J. Biol. Chem., 66, 375 (1925).

${ }^{B}$ Pearson, S., Stern, S., and MeGavack, T. H., Anal. Chem., 25, 813 (1958).

\section{PHYSIOLOGY}

\section{Function of the Uncrossed Efferent Olivo- cochlear Fibres in the Cat}

RECENT anatomical evidence obtained in the cat indicates that two sets of nerve fibres actually contribute to the efferent bundle (Rasmussen) which forms the anastomosis of Oort between vestibular and cochlear nerves and which travels centrifugally towards the organ of Corti in the inner ear. Approximately three-quarters of the fibres are crossed and originate from small neurones adjacent to the accessory nucleus of the oliva superior on the opposite side of the brain-stem ${ }^{1}$. The remaining quarter of these efferent axons originates from neurones located on the dorsal aspect of the principal S-shaped nucleus of the oliva superior on the same side ${ }^{2}$. Many data have been collected on the function of the crossed component ${ }^{8-6}$, which can be activated at its decussation under the floor of the fourth ventricle (Fig. 1, F) and the inhibitory effect of which on auditory input is quite powerful, ranging up to $\mathrm{a}-25 \mathrm{db}$ equivalent attenuation of sound energy ${ }^{6}$. A special feature of this pure inhibitory pathway is that the (long) axons available for stimulation synapse directly on to afferent auditory terminals and hair cells with no interposed interneurone ${ }^{2,7}$. The uncrossed efforent fibres also establish direct connexions with the inner ear structures7, but their functional properties are still unknown.

This communication describes experiments on adult cats, anæsthetized with $\alpha$-chloralose or with pontobarbital, curarized with 'Flaxedil' and with middle ear muscles cauterized to prevent changes in sound transmission up to the oval window. Our plan was to stimulate efferent fibres through bipolar steel electrodes inserted through the intact cerebellum into the brain-stem, and to look for changes in the acoustic evoked potentials recorded from the exposed round window (Fig. 1, $A$ ). The programming apparatus and other technical details have been described elsewher $\theta^{6}$. Electrode locations were checked in serial paraffin sections through the fixed brain (prussian blue marks). Controls have shown that with our procedure of stereotaxic stimulation through closely spaced fine needles, movement of the electrode by $a$ fraction of a millimetre can change the electrical threshold of the efferent effect ${ }^{8}$. Therefore we think that the stimulation 1 (Fig. 1, F) activates only the crossed olivo-cochlear fibres for either ears at their decussation, hence the bilateral gating observed in $C$. Stimulation 2 on the right side does not affect the $N_{3}-N_{2}$ potentials recorded on the 